\title{
Blended Learning: Post Pandemic Solutions
}

\author{
Seriwati Ginting, Miki Tjandra, Elizabeth Wianto \\ Fakultas Seni Rupa dan Desain \\ Universitas Kristen Maranatha \\ seriwati.ginting@maranatha.edu
}

\author{
Received: 12 Januari 2021; Revised: 26 Februari 2021; Accepted: 28 April 2021 \\ DOI: http://dx.doi.org/10.37905/aksara.7.2.425-438.2021
}

\begin{abstract}
Abstrak
Pandemi telah mengubah pembelajaran tatap muka menjadi Pembelajaran Jarak Jauh (PJJ) yang menimbulkan kendala seperti ketidaksiapan menggunakan aplikasi pembelajaran online, belum tersedianya materi untuk diunggah, jaringan internet yang tidak stabil, biaya kuota internet, dan kejenuhan siswa. Penelitian ini bertujuan untuk memberikan gambaran pelaksanaan PJJ dan upaya implementasi blended learning sebagai solusi proses pembelajaran di sekolah dasar dan sekolah menengah pertama. Metode penelitian yang digunakan adalah kuantitatif dan kualitatif, melalui observasi, wawancara, kuesioner dan dokumentasi. Hasil penelitian menunjukkan kombinasi dari pembelajaran online, offline dan tatap muka mampu menciptakan suasana yang lebih menyenangkan bagi siswa, guru dan orang tua.
\end{abstract}

Kata kunci: blended learning, pembelajaran jarak jauh, proses pembelajaran.

\begin{abstract}
The pandemic has transformed face-to-face learning into distance learning which has caused obstacles such as unpreparedness to use online learning applications, unavailability of material to upload, unstable internet networks, internet quota fees, and student saturation. This study aims to provide an overview of the implementation of distance learning and efforts to implement blended learning as a solution for the learning process in elementary and junior high schools. The research methods used are quantitative and qualitative through observation, interview, questionnaire, and documentation. The results showed that the combination of online, offline, and face-toface learning could create a more pleasant atmosphere for students, teachers, and parents.
\end{abstract}

Keywords: blended learning, distance learning, learning process.

\section{Introduction}

Distance Learning has become the only learning option during the Covid-19 pandemic, as an effort to break the spread of the virus chain. At the beginning of the implementation of distance learning, almost every school in Bandung encountered obstacles whether in the equipment constraints, the internet network that is not yet available, the ability of human resources to use the equipment, the preparation of 
teaching materials, the readiness of students and parents, and the communication between parents, teachers and students. Some schools are better prepared because they have previously carried out the learning process with a combination of face-to-face (conventional) learning with learning process that takes advantage of technological advances and variations in teaching and learning activities, which is only done at times and not for the whole learning process. The city of Bandung has implemented distance learning since March 2020, as a follow-up to Circular Letter Number 3 of 2020 on the Education Unit and Number 36962 / MPK.A / HK / 2020 concerning the implementation of education during the coronavirus disease 2019 (Covid-19). This sudden change was confusing for some schools that had never tried online learning.

This research was conducted during pandemic and new normal situation. The purpose of this study was to obtain a real picture and conditions in the field related to the readiness of schools, teachers, parents and students, as well as what solutions are most likely to be carried out during the pandemic and new normal time. The Covid-19 pandemic is an event that was unpredictable, however the teaching and learning process must continue, regardless of the conditions that are being faced. Some studies in the field of education that tried to combine several learning methods before the pandemic have not received much response. Some schools that responded were carried out the process of combining online, offline and onsite learning as part of the learning process, whic is known as blended learning.

Blended learning combines the best characteristics of learning in class (face-toface) and the best characteristics of online learning, namely so that students are active and reduce the amount of face-to-face time in class (Khoiroh, Munoto, \& Anifah, 2017) so that direct interaction between teachers and students stay intertwined. Through blended learning students explore learning resources from the internet and not only waiting for lectures and materials from the teacher as if the teacher knows everything and is the only source of learning. Blended learning provides opportunities for students to open new horizons, and it turns out to be fun for students including elementary school students (Widyaningsih, Yudha, \& Nugraheny, 2016). The implementation of blended learning is basically the efforts of teachers to develop their competencies by keeping up with advances in technology and information (Law of the Republic of Indonesia Number 14 of 2005 Concerning Teachers and Lecturers, 2005). The readiness of blended learning requires cooperation and support from all components involved, including educational institutions.

Educational institutions must anticipate quickly (Snelling \& Fingal, 2020). Some teachers are confused because some materials are not ready to be uploaded, and the way to upload the materials are still unfamiliar. It is also confusing for students and parents to use learning applications. However, because the teaching and learning process must be carried out, preparations are carried out "as is". The school tries to provide an internet network so that teachers can prepare teaching materials for distance learning. Parents in a short time learn Google Classroom, Zoom, WhatsApp Group, Google Meet, MS Team and others. School managers, students, parents, teachers must migrate to digital or online learning systems and teachers must be prepared for various learning conditions and student conditions, including the development of life in the community (Wahyono, Husamah, \& Budi, 2020) . 


\section{Method}

This study combines qualitative and quantitative methods by collecting and analyzing data to obtain information about the implementation of online learning which is carried out in full at the elementary and junior high school levels by conducting surveys, distributing questionnaires and interviews as well as data processing. The questionnaires were filled out by three hundred and one (301) respondents consisting of 25 primary school / small class students (grades 1-3), 22 elementary school / large class students (grades 4-6), 113 junior high school students, 42 teachers, and 99 parents. The results of the questionnaire are then assessed / scored to complement the interview data. Interviews were conducted using purposive sampling technique, selected with the consideration of direct involvement in online learning, by taking into account the social situation which consists of three elements, namely place, actor and activity that interact synergistically (Sugiyono, 2014). The interview involved 11 elementary school students, (grade 1-3 students totaling 5 people, grade 4-6 students totaling 6 people), 15 junior high school students, 9 elementary school teachers and 8 junior high school teachers. Interviews with school principals involved 2 primary school principals and 2 junior high school principals. Interviews were also conducted with 3 parents of elementary school students and 3 parents of junior high school students. Interviews for elementary schools were grouped into small classes and large classes to obtain information they felt was related to readiness to take online classes independently (observations and interviews of small class students needed parental assistance more than large class students). Junior high school students are generally independent when they follow distance learning.

Interviews were conducted online and onsite by paying attention to health protocols. To complete the results of observations and interviews, a questionnaire was also prepared using the Google Form, which was distributed to elementary school students, junior high school students, teachers, parents and school principals (SD and SMP). The results of questionnaire processing are used to complement the results of observations, interviews and documentation so that the information obtained becomes more complete. Data analysis was carried out by the stages of data reduction, data display and conclusion / verification.

\section{Results and Discussion}

The implementation of distance learning is carried out simultaneously to break the chain of virus spread. Circular letter number 3 issued by the government on March 182020 caused all indoor and outdoor activities in all sectors to be postponed, especially in the education sector. During the pandemic period; time, location and distance are big problems (Kusuma \& Hamidah, 2020). So that distance learning becomes a solution to overcome difficulties in carrying out face-to-face learning (Herliandry, Nurhasanah, Suban, \& Kuswanto, 2020). The infrastructure used to support free online learning through WhatsApp Rooms, Smart Classes, Zenius, Quipper and Google Classrooms (Abidah, Hidaayatullaah, Simamora, Fehabutar, \& Mutakinati, 2020) . The learning process should ideally apply face-to-face, online and offline learning. The learning process that only utilizes technology or only applies e-learning cannot be fully successful, because each student's learning style is different (Wardani, Toenlioe, \& Wedi, 2018). Learning styles are grouped into three, namely visual learning 
styles, audio learning styles and kinesthetic learning styles. Students who have audio and visual learning styles will feel more suited to e-learning while students who have a kinesthetic learning style will be more interested in learning face-to-face (quoted by Nikmawati, 2014) according to Bobby De Porter and Mike Hernacki.

Technological developments are used by schools to deal with unforeseen circumstances affecting teaching and learning activities including the Covid-19 pandemic. Schools must find new alternatives to implement learning and online/virtual learning is the most feasible (Arora \& Srinivasan, 2020). The pandemic condition causes the teaching and learning process not running as it should, and teachers cannot witness the complete learning process. Education is not just transfer of knowledge but how values in education are manifested. The United Nations, through UNESCO, which handles the education sector, has set four educational goals called the four pillars of education which consist of: (1) learning to know, (2) learning to do, (3) learning to be and (4) learning to live together ( http://www.ibe.unesco.org/ en/glossary-curriculumterminology/f/four-pillars-oriented-curriculum-design). The implementation of distance learning can accommodate points 1 and point 2 of the goals set by UNESCO, namely students know and carry out instructions from the teachers but for point 3 about whether students carry out instructions based on internal encouragement, motivation that comes from within is difficult to measure. Likewise with point 4 because the situation was not possible, students did not interact with friends and teachers so that they could not be assessed.

Assistance, parental guidance and coordination with teachers are needed (Dewi, 2020). Blended learning can increase student motivation, critical attitude and achievement (Manggabarani, Sugiarti, \& Masri, 2016; Masitoh, Yuliyanti, Lestari, \& Fitriyah, 2018). Of course, there needs to be a selection of teaching materials that are delivered online with teaching materials that are delivered offline. It is necessary to consider the readiness of students from the aspects of their three psychological needs, namely: linkages, competence and autonomy (Wong, 2019), because even though elementary school students represent the alpha generation or commonly referred to as the 21 st century generation and have familiar characteristics with technology, the readiness of the new learning styles are still necessary to be considered by the roles of teachers and students (Rombot, 2020), the technology used (Pimmer, 2016), and the possibility of changes in social interactions (Chang-Tik, 2018). The readiness of teachers in accessing and using technology in the teaching and learning process is a must and cannot be negotiated. The teacher must have the initiative in selecting and determining the learning media for each topic that is conveyed appropriately. Teacher initiatives really help foster student motivation in learning. Initiatives require care and sensitivity to their duties and functions (Ginting, 2013).

Teachers who have the initiative will be more innovative in presenting learning materials by developing various learning media (Octaviany Widyaningsih et al., 2016). Post-pandemic becomes a normal condition in future situation after pandemic, which will affect how we work and various activities of human life (Schenker, 2020). The pandemic provides many lessons including education. Before the pandemic the teaching and learning process was carried out conventionally, everything was carried out in schools (face-to-face), during the pandemic all school activities were carried out remotely (online and offline) then after the pandemic school activities could be carried 
out in combination (blended learning), face to face, online and offline. The combination of face-to-face, online and offline learning is believed to be a fun variation for both students and teachers (Drysdale, Graham, Spring, \& Halverson, 2013; Khoiroh et al., 2017; Suhartono, 2016).

\section{Results}

Application of distance learning is not always easy, there are several obstacles faced in its implementation. The following are the findings when online learning is carried out simultaneously. Some schools are more ready to do it because they have implemented distance learning as part of the learning process even though it has not been done regularly, so they already have an internet network, teaching materials have been uploaded, students have done online learning several times and parents have also been familiar with several application media teaching such as whatsapp group and some parents have tried the zoom application. However, there are schools that have never tried online learning. For schools that have never tried online learning, there are those that already have an internet network at their school. The use of the internet to find teaching material so that when delivering material to students it is not only from books. Schools that do not yet have an internet network have a bigger problem, because they require time to apply for a network installation. For students, who usually study in class with the atmosphere of many friends, meeting directly with the teacher is now inversely proportional to studying at home, even though the ability and absorption of each student is different. When teachers and students meet directly in the classroom, it is easier for the teacher to monitor the level of understanding, development or readiness of students for the material that has been taught before the teacher changes the topic with the next material (Mastura \& Santaria, 2020). The following are the findings in the implementation of distance learning.

A. The Views and Constraints of Elementary and Junior High School Teachers are Summarized as Follows:

a. Not all teachers have teaching materials to upload.

b. Some teachers have prepared material in Power Point (PPT), but not all teachers can or are good at uploading the material.

c. Not all teachers have personal laptops.

d. Limited budget for internet quota.

e. Unstable network.

f. Explaining material to students is more difficult (especially for counting materials, such as mathematics and physics).

g. Students are not really ready (some just wake up a few minutes before distance learning is implemented).

$\mathrm{h}$. The teacher is very busy preparing interesting materials and preparing learning videos.

i. Online learning time feels very long, especially when student responses become more passive when compared to face-to-face learning.

j. Limited learning video playback through distance learning.

k. Cannot observe students directly while working on assignments. 
1. The time to convey the values of life is very limited because it focuses more on teaching materials, the goal is to save quota costs.

m. Cannot observe the psychological development of students (students who are having problems with their families, have difficulty following lessons).

n. Relationships with students feel more distant.

o. It is difficult to measure the level of student understanding of the material that has been presented.

p. Difficult to know student workload (students receive many assignments at the same time).

Table 1 Teacher Statement Table

\begin{tabular}{|c|c|c|c|c|c|c|}
\hline NO. & QUESTION & $\begin{array}{l}\text { STRONGLY } \\
\text { AGREE }\end{array}$ & AGREE & NEUTRAL & DISAGREE & $\begin{array}{l}\text { STRONGLY } \\
\text { DISAGREE }\end{array}$ \\
\hline 1 & $\begin{array}{l}\text { Material for uploading } \\
\text { existed before the pandemic }\end{array}$ & $16.7 \%$ & $33.3 \%$ & $35.7 \%$ & $7.1 \%$ & $7.1 \%$ \\
\hline 2 & $\begin{array}{l}\text { The internet network is } \\
\text { always stable }\end{array}$ & $4.8 \%$ & $33.3 \%$ & $33.3 \%$ & $19 \%$ & $9.5 \%$ \\
\hline 3 & $\begin{array}{l}\text { Distance learning is more } \\
\text { fun }\end{array}$ & $0 \%$ & $7.1 \%$ & $40.5 \%$ & $33.3 \%$ & $19 \%$ \\
\hline 4 & $\begin{array}{l}\text { Teaching online is more } \\
\text { difficult than teaching face- } \\
\text { to-face }\end{array}$ & $21.4 \%$ & $33.3 \%$ & $26.2 \%$ & $14.3 \%$ & $4.8 \%$ \\
\hline 5 & $\begin{array}{l}\text { The cost for the quota is } \\
\text { provided by the school }\end{array}$ & $19 \%$ & $26.2 \%$ & $40.5 \%$ & $9.5 \%$ & $4.8 \%$ \\
\hline 6 & $\begin{array}{l}\text { Distance learning media } \\
\text { uses Google Classroom }\end{array}$ & $22 \%$ & $26.8 \%$ & $34.1 \%$ & $9.8 \%$ & $7.3 \%$ \\
\hline 7 & $\begin{array}{l}\text { Distance learning media } \\
\text { uses WhatsApp group }\end{array}$ & $31 \%$ & $19 \%$ & $40.5 \%$ & $9.5 \%$ & $0 \%$ \\
\hline 8 & $\begin{array}{l}\text { Distance learning media } \\
\text { uses Zoom }\end{array}$ & $22 \%$ & $31.7 \%$ & $26.8 \%$ & $7.3 \%$ & $12.2 \%$ \\
\hline 9 & $\begin{array}{l}\text { Distance learning media } \\
\text { uses Telegram group }\end{array}$ & $0 \%$ & $9.8 \%$ & $39 \%$ & $22 \%$ & $29.3 \%$ \\
\hline 10 & Tasks are assigned offline & $9.5 \%$ & $31 \%$ & $42.9 \%$ & $7.1 \%$ & $9.5 \%$ \\
\hline 11 & $\begin{array}{l}\text { It's easier to teach face to } \\
\text { face }\end{array}$ & $50 \%$ & $16.7 \%$ & $33.3 \%$ & $0 \%$ & $0 \%$ \\
\hline 12 & $\begin{array}{l}\text { It is more difficult to explain } \\
\text { material online }\end{array}$ & $33.3 \%$ & $14.3 \%$ & $35.7 \%$ & $11.9 \%$ & $4.8 \%$ \\
\hline 13 & $\begin{array}{l}\text { Online learning videos have } \\
\text { been prepared }\end{array}$ & $11.9 \%$ & $33.3 \%$ & $42.9 \%$ & $11.9 \%$ & $0 \%$ \\
\hline 14 & $\begin{array}{l}\text { Difficulty preparing an } \\
\text { attractive PPT }\end{array}$ & $21.4 \%$ & $16.7 \%$ & $40.5 \%$ & $11.9 \%$ & $9.5 \%$ \\
\hline
\end{tabular}

(Source: Questionnaire Results)

\section{B. The Views and Concerns of Elementary and Junior High Schools Parents are Summarized as Follows:}

a. Parents of small classes (grades 1-3 SD) complain about the difficulty of teaching children who feel more comfortable studying with their teachers and friends. 
b. It is difficult to explain to young children about the Covid-19 pandemic and its impact on health, when children continue to ask questions why they should be at home, why not go to school.

c. Can't be patient to teach children, especially for arithmetic lessons.

d. Difficulty dividing time between accompanying children and doing office tasks.

e. Thirty-five percent of parents said they were unfamiliar with the learning facilities chosen / determined by the school.

f. Forty percent of small class parents said they were overwhelmed because they had to accompany them during online meeting. The child's attention can easily change if not accompanied. The children will look for toys, play with toys and always seems to be yawning. The children do not concentrate on the material presented, especially if the learning uses the lecture method and is more than twenty minutes.

g. Sixty percent of parents complained about the cost of internet quotas.

h. Thirty percent complained about the unstable network.

i. Parents from grades seven and eight complained about their child's addiction to playing games when not on distance learning.

j. In the morning it is more difficult to wake up, children just wake up when the classroom is opened and even only wash their faces and change their uniforms, and when the camera is closed the children do not focus on what the teacher says.

$\mathrm{k}$. Video playback as a learning tool is more interesting.

1. Do not understand the material being studied (complained by parents from grade 5 to grade 9 ).

$\mathrm{m}$. The digital equipments owned is not enough for every family member who is doing distance learning and work from home at the same time.

n. Parents become the one who learn the study materials, not the children.

o. Children complain a lot, bored, and school work piles up. 
Table 2 Parents Statement Table

\begin{tabular}{|c|c|c|c|c|c|c|}
\hline NO. & QUESTION & $\begin{array}{l}\text { STRONGLY } \\
\text { AGREE }\end{array}$ & AGREE & NEUTRAL & DISAGREE & $\begin{array}{l}\text { STRONGLY } \\
\text { DISAGREE }\end{array}$ \\
\hline 1 & $\begin{array}{l}\text { Prefer children to study at } \\
\text { school }\end{array}$ & $54.2 \%$ & $19.2 \%$ & $17.5 \%$ & $3.4 \%$ & $5.6 \%$ \\
\hline 2 & $\begin{array}{l}\text { Children are more difficult } \\
\text { to manage }\end{array}$ & $19.1 \%$ & $14 \%$ & $30.3 \%$ & $19.1 \%$ & $17.4 \%$ \\
\hline 3 & $\begin{array}{l}\text { The internet network is } \\
\text { always stable }\end{array}$ & $12.9 \%$ & $19.7 \%$ & $32 \%$ & $21.9 \%$ & $13.5 \%$ \\
\hline 4 & $\begin{array}{l}\text { Internet quota fees are not a } \\
\text { problem }\end{array}$ & $20.2 \%$ & $16.3 \%$ & $21.3 \%$ & $20.2 \%$ & $21.9 \%$ \\
\hline 5 & $\begin{array}{l}\text { Answer children's questions } \\
\text { patiently }\end{array}$ & $22.5 \%$ & $27.5 \%$ & $29.2 \%$ & $15.7 \%$ & $5.1 \%$ \\
\hline 6 & $\begin{array}{l}\text { Difficulty uploading } \\
\text { assignments }\end{array}$ & $12.4 \%$ & $15.3 \%$ & $29.4 \%$ & $21.5 \%$ & $21.5 \%$ \\
\hline 7 & $\begin{array}{l}\text { Difficult to find materials / } \\
\text { references }\end{array}$ & $10.7 \%$ & $21.9 \%$ & $30.9 \%$ & $18.5 \%$ & $18 \%$ \\
\hline 8 & $\begin{array}{l}\text { There are too many } \\
\text { children's tasks }\end{array}$ & $16.4 \%$ & $24.3 \%$ & $37.9 \%$ & $12.4 \%$ & $9 \%$ \\
\hline 9 & $\begin{array}{l}\text { Children prefer to study } \\
\text { with the teacher }\end{array}$ & $49.7 \%$ & $24.3 \%$ & $18.1 \%$ & $6.8 \%$ & $1.1 \%$ \\
\hline 10 & $\begin{array}{l}\text { Children complain of } \\
\text { boredom / saturation }\end{array}$ & $46.3 \%$ & $20.9 \%$ & $20.3 \%$ & $10.2 \%$ & $2.3 \%$ \\
\hline
\end{tabular}

(Source: Questionnaire Results)

\section{The Opinions of Elementary and Junior High School Students are Summarized as Follows:}

a. Feel bored.

b. Missed school.

c. Missed friends.

d. Eyes sting when staring at the monitor screen for too long.

e. Monotonous, unattractive.

f. The teacher starts directly with the material, only greeting a few students.

g. Prefer to study with teachers than with parents.

h. It is more difficult to understand counting lessons compared when they are explained at school (face-to-face).

i. Unstable network.

j. Too many tasks.

k. Parents cannot answer questions asked about the subject matter.

1. Parents often get angry when asked about lessons.

m. Parents shift responsibility to one another. When asking to father, they were told to ask mom and vice versa. 
Table 3 Students Statement Table

\begin{tabular}{|c|c|c|c|c|c|c|}
\hline NO. & QUESTION & $\begin{array}{l}\text { STRONGLY } \\
\text { AGREE }\end{array}$ & AGREE & NEUTRAL & DISAGREE & $\begin{array}{l}\text { STRONGLY } \\
\text { DISAGREE }\end{array}$ \\
\hline 1 & $\begin{array}{l}\text { Prefer to learn face-to-face } \\
\text { at school }\end{array}$ & $48.3 \%$ & $24.6 \%$ & $22.9 \%$ & $0.8 \%$ & $3.4 \%$ \\
\hline 2 & Distance learning is boring & $25.4 \%$ & $22 \%$ & $36.4 \%$ & $12.7 \%$ & $3.4 \%$ \\
\hline 3 & $\begin{array}{l}\text { The internet network is } \\
\text { always stable }\end{array}$ & $12.7 \%$ & $22 \%$ & $30.5 \%$ & $24.6 \%$ & $10.2 \%$ \\
\hline 4 & $\begin{array}{l}\text { Internet quota is always } \\
\text { available }\end{array}$ & $19.7 \%$ & $18.8 \%$ & $29.1 \%$ & $21.4 \%$ & $11.1 \%$ \\
\hline 5 & More tasks & $29.7 \%$ & $25.4 \%$ & $30.5 \%$ & $8.5 \%$ & $5.9 \%$ \\
\hline 6 & The task is more difficult & $20.3 \%$ & $27.1 \%$ & $42.4 \%$ & $5.9 \%$ & $4.2 \%$ \\
\hline 7 & $\begin{array}{l}\text { Understand and can follow } \\
\text { the teacher's explanation }\end{array}$ & $6.9 \%$ & $21.6 \%$ & $44.8 \%$ & $20.7 \%$ & $6 \%$ \\
\hline 8 & $\begin{array}{l}\text { Counting material is more } \\
\text { difficult to understand }\end{array}$ & $26.5 \%$ & $25.6 \%$ & $30.8 \%$ & $14.5 \%$ & $2.6 \%$ \\
\hline 9 & PPT is boring & $15.8 \%$ & $21.1 \%$ & $47.4 \%$ & $12.3 \%$ & $3.5 \%$ \\
\hline 10 & I prefer to learn via video & $12.1 \%$ & $18.1 \%$ & $32.8 \%$ & $25 \%$ & $12.1 \%$ \\
\hline 11 & Prefer to study at home & $6.8 \%$ & $8.5 \%$ & $33.3 \%$ & $26.5 \%$ & $24.8 \%$ \\
\hline 12 & Can wake up later & $17.2 \%$ & $12.9 \%$ & $27.6 \%$ & $17.2 \%$ & $25 \%$ \\
\hline 13 & $\begin{array}{l}\text { My parents always } \\
\text { accompany me during } \\
\text { distance learning }\end{array}$ & $7.8 \%$ & $7.8 \%$ & $36.2 \%$ & $26.7 \%$ & $21.6 \%$ \\
\hline 14 & $\begin{array}{l}\text { Parents patiently answered } \\
\text { my questions }\end{array}$ & $13.8 \%$ & $18.1 \%$ & $31.9 \%$ & $23.3 \%$ & $12.9 \%$ \\
\hline 15 & Never run out of quota & $35 \%$ & $25.6 \%$ & $16.2 \%$ & $6.8 \%$ & $16.2 \%$ \\
\hline 16 & Never attended class too late & $18.8 \%$ & $28.2 \%$ & $22.2 \%$ & $6.8 \%$ & $23.9 \%$ \\
\hline 17 & $\begin{array}{l}\text { Never went out the lights } \\
\text { (flow) during distance } \\
\text { learning }\end{array}$ & $26.5 \%$ & $10.3 \%$ & $17.1 \%$ & $15.4 \%$ & $30.8 \%$ \\
\hline 18 & $\begin{array}{l}\text { Assignments are assigned } \\
\text { offline }\end{array}$ & $17.9 \%$ & $16.2 \%$ & $35 \%$ & $10.3 \%$ & $20.5 \%$ \\
\hline 19 & Missed school & $62.4 \%$ & $15.4 \%$ & $17.1 \%$ & $4.3 \%$ & $0.9 \%$ \\
\hline 20 & Missed friends & $64.1 \%$ & $13.7 \%$ & $17.1 \%$ & $3.4 \%$ & $1.7 \%$ \\
\hline
\end{tabular}

(Source: Questionnaire Results)

\section{Discussions}

Another impact of distance learning is the formation of untouched student character. Character building occurs when there is interaction at home, at school, and also in the environment, such as the saying "actions will speak louder than words" (Badudu, 2019). Distance learning or e-learning, no matter how sophisticated the technology used, has not been able to replace the implementation of face-to-face learning because the conventional face-to-face interaction method is still much more effective than online learning (Dwi, Amelia, Hasanah, \& Putra, 2020). All literature in e-learning indicates that not all students will be successful in online learning, due to learning environment factors and student characteristics (Nakayama, Yamamoto, \& Santiago, 2007). This shows that combined learning or blended learning can be used as a solution in teaching and learning activities. The duties of teachers as a profession include (1) educating, or continuing and developing life values, (2) teaching, means continuing and developing science and technology and (3) training, namely by 
developing skills for students (Asmawati, Masaong, \& Mas, 2020). Learning requires direct interaction, direct savings and direct viewing.

In distance learning, communication and interaction are limited on-screen within a short time duration. The children growing and developing process only occur at home. Parents work while the children are at home. This condition is boring and very likely makes children confused. The choices made after participating in distance learning are playing games, opening various existing online features, choosing them according to your heart's desire without supervision and assistance. If this happens for a long time, there will be a shift in behavior. It is difficult for a small child to be expected to behave in accordance with the prevailing moral values by himself, understanding what the environment demands of him (Gunarsa \& Gunarsa, 2017). The pandemic has not yet passed, but this condition also needs to be dealt with by seeking blended learning, on a limited scale. Face-to-face meetings at school are important by paying attention to health protocols such as the use of masks, provision of hand sanitizers, room ventilation, body temperature checks, the number of students going to school is limited and carried out alternately with face-to-face times twice a week while following and monitoring developments from the government.

\section{a. Why Blended Learning?}

Blended learning as a combination of learning process becomes a solution because it can be used in all situations with due regard to conditions. During the pandemic, faceto-face learning is given a smaller portion (health protocols are still considered), but there is a balance for the mental development of children when meeting and greeting teachers and friends. The teacher pays close attention to the children keeping their distance, not shaking hands or hugging each other, but they can chat directly, can stare at each other and exchange stories even though maybe a little screaming occured. If deemed necessary, students and teachers can use gloves during their activities at school. The duration of time is also limited, unlike in normal circumstances. When meeting face-to-face at school, prioritize exact lessons that are difficult for students to understand when they go through distance learning in full, always insert moral messages such as obeying rules, staying enthusiastic, respecting parents, staying patient and sharing with the less fortunate. Maintain a balance of cognitive, affective and psychomotor aspects of students. For schools that do not have an internet network, there is no other choice they have to prepare it. Funding is often an obstacle in maximizing online learning (Yaumi, 2018).

The school needs to; register teachers who do not have laptops, finding and choosing resource persons to support online learning (carrying out interesting PPT training, training using teaching applications, uploading materials) then scheduling them. Supporting teachers to do online learning from schools for those who do not have laptops, wifi or whose home network is unstable. Conducting meetings with parents via online as an effort to socialize especially mentoring students, learning applications, teaching and learning process procedures, collecting assignments, implementing UTS and UAS. Make revisions to the regular learning schedule. Coordinating with teachers in giving assignments to students so that they are not too many assignments. The principal as the highest leader in the school needs to be alert and quick to make decisions. The principal can still carry out his leadership well in the midst of a crisis (Murfi, Fathurrochman, Atika, \& Saiva Jannana, 2020). Entering the new normal face- 
to-face learning needs to be arranged by paying attention to health protocols.

\section{b. Implementation of Blended Learning in Elementary Schools and Junior High Schools}

Teachers need to adapt quickly, open themselves up (realizing that teachers are not the only source of learning) want to learn using the zoom application, ms team, google classroom and other learning media, prepare online material, search for and find supporting learning resources, choose learning methods most likely for each class being taught. Willing to spend more time in preparing teaching materials. Select and determine teaching materials that are prepared for online and teaching materials for offline. Set the duration of online learning time, the duration of time needs to take into account the age of the child. For small classes, online time should be limited to a maximum of twenty minutes. Playing short videos (duration 3 minutes) related to the teaching material can help students be more prepared to take lessons. Teachers aged fifty and over complain of being slower in absorbing training materials and in using the zoom and google classroom applications. To overcome face-to-face learning difficulties and schools remain active even though schools are closed, blended learning is a solution (Herliandry et al., 2020).

Online learning demands the role of educators to carry out evaluations tailored to learning needs that meet aspects of knowledge, morals and skills (Dai \& Lin, 2020). The teacher felt that something was missing because they could not see directly the students' ability to absorb, what the students felt through their attitudes and students turned out to be more passive, when distance learning preferred to close the camera and when the camera was opened the students looked discouraged, not passionate, most of them did not. staring at the camera, there is an impression of saturation. When asked, students opened the camera, then answered briefly. It is difficult for teachers to build emotional closeness with students, in contrast to face-to-face learning in schools. Time to face through online feels long, because it is only one way.

To be able to implement blended learning, it is not only teachers and schools that need to continue to adapt to the various changes that occur, but also parents and students. Most parents accompany their children at the beginning of the pandemic because parents implement work from home, but sometimes it is difficult because the time between work from home and distance learning is often the same so that when there are assignments and children ask questions, sometimes they cannot answer because when the teacher explains they are not accompanied. Another complaint is the limited smartphone and laptop equipment (the number of family members who use more than the equipment they own). Parents who experienced pay cuts / wage cuts complain that the cost of internet quota adds to their living expenses. Another complaint is that parents feel teaching their children is an additional burden, especially for math class 4 to grade 6 which is not understood. Before the pandemic, children received additional lessons, or if they did not understand, they could study together with friends. Middle school parents complained about the same thing. Difficulty answering children's questions for Physics and Chemistry questions. Online learning requires the support of parents in providing online education facilities (Obiakor \& Adeniran, 2020), as well as intensive assistance, especially for small class students who easily shift their concentration, tend to be gloomy and protest wanting to study at school. But there are 
also positive things that parents feel, because they spend more time with family, so they know more about the nature of the child, children become more open in expressing their feelings, doing household chores together and knowing and feeling the challenges faced by children in carrying out online learning.

The results of observations and interviews with students obtained a summary of the answers as follows; At the beginning of the pandemic, students felt happy because they gathered together at home, could wake up late but then began to complain of boredom, tired eyes, many tasks and missed the school atmosphere. Calculation lessons are difficult to apply through distance learning. Parents can't wait to be there, when asked, they tend to get angry and say, "Watch if the teacher explains." Students' complaints included, "I don't understand math especially online", "It turns out that studying at school is more fun than distance learning", "Now it's confined to only holding a cellphone, especially when parents have started working, it's getting harder to ask questions about lessons", "When you come home from work, you are asked, later mom will be tired and then the lessons that you don't understand will pass, just like that the next week there is new material, so it's more difficult to understand", "The teacher's voice is monotonous, like a bedtime fairy tale, lacking enthusiasm", "Face to face online is too long, bored". These student complaints become input for teachers to prepare teaching materials that are more attractive to students.

Distance learning is inevitable because the situation and conditions do not allow the full teaching and learning process to be carried out in schools. However, distance learning can be combined with offline learning (cost-effective, can be opened / studied anywhere) and limited onsite learning. The combination of online, offline and onsite turns out to provide a harmonious balance in students and of course good for character development. Through online learning students can attend lessons from home without having to go to school, save time, don't get jammed, don't incur costs / transportation and can enjoy being together with their families. When offline students can open teaching materials or repeat material without having an internet network available. Students can repeat lessons anytime, anywhere so that understanding of the teaching material is better mastered / understood. When learning onsite (by still paying attention to health protocols) students' longing for the school atmosphere, meeting friends, meeting face-to-face with teacher, asking questions can be more detailed and enjoying the trip to and from school. Blended learning that is carried out in a balanced manner is a solution that can be carried out by educational institutions by paying attention to the readiness of all components involved in it.

\section{CONCLUSION}

The teaching and learning process is an activity that is carried out in a planned and sustainable manner in shaping a person as a whole. Whatever the conditions, the teaching and learning process is a top priority in the world of education. The Covid-19 pandemic that came suddenly pushed the implementation of distance learning in full. However, there were various obstacles and also impacts on children's character development. Before Covid-19, the implementation of blended learning was only situational, as a variation and as an option to complement face-to-face learning, but during Covid-19 and new normal, blended learning were the most likely to be implemented. Blended learning can be adjusted according to the situation and conditions. As social creatures, children need "face-to-face meetings" with their teachers and friends. The implementation of blended 
learning can be done in collaboration between schools, teachers, parents and students. Communication between the school, teachers and parents needs to be continuously built. It needs coordination among teachers so that the student learning load is not too much (logical and measurable).

The limitations of smartphones are also a problem. Schools can collaborate with parents of students who are very likely to have smartphones that are no longer in use but can still be used. Set the number and class schedule of students. In its development through interviews, it was found that students agreed that face-to-face school combined with e-learning learning was more fun and more challenging. Learning activities in class are accompanied by direct greetings from the teacher, reprimands / corrections of the teacher when making mistakes such as entering class without knocking on the door and saying greetings. Issuing harsh words, when arguing with friends turns out to be missed as well as praise with a smile on your face teachers are fun things for students. Each learning method has advantages and disadvantages. Conventional learning requires students and teachers to be at the same time and place, teachers tend to lecture so that students only hear and do not get a place to express ideas, the advantage is that the teacher can observe directly if there are students who do not understand or understand the material explained, monitor and directing when students do the wrong task or behavior that is not praiseworthy. The interactions that exist make the emotional bond between the teacher and students closer. In distance learning, the relationship between teachers and students becomes distant. Face-to-face in cyberspace certainly limits the teacher's monitoring and supervision of students, students' expressions are difficult for the teacher to interpret correctly. The advantage is that teachers are more creative in presenting teaching materials, students are given space to complete teaching materials. By combining online, offline and face-to-face learning methods, it will complement each other and make learning more effective and meaningful.

\section{REFERENCES}

Abidah, A., Hidaayatullaah, H. N., Simamora, R. M., Fehabutar, D., \& Mutakinati, L. (2020). The Impact of Covid-19 to Indonesian Education and Its Relation to the Philosophy of "Merdeka Belajar." Studies in Philosophy of Science and Education, 1(1 SE-Articles), 38-49. https://doi.org/10.46627/sipose.v1i1.9

Arora, A. K., \& Srinivasan, R. (2020). Impact of pandemic covid-19 on the teaching - learning process: A study of higher education teachers. Prabandhan: Indian Journal of Management. https://doi.org/10.17010/pijom/2020/v13i4/151825

Asmawati, Masaong, K., \& Mas, R. (2020). Evaluasi Kinerja Guru dalam Pembinaan Karakter Siswa. In Era Baru Manajemen Pendidikan: Aplikasi, Strategi, dan Inovasi. Bandung: Ideas Publishing.

Badudu, R. (2019). Character Excellence: Mengembangkan Karakter Pribadi. Jakarta: Kompas Media Nusantara.

Chang-Tik, C. (2018). Impact of learning styles on the community of inquiry presences in multidisciplinary blended learning environments. Interactive Learning Environments, 26(6), 827-838. https://doi.org/10.1080/10494820.2017.1419495

Dai, D., \& Lin, G. (2020). Online Home Study Plan for Postponed 2020 Spring Semester during the COVID-19 Epidemic: A Case Study of Tangquan Middle School in Nanjing, Jiangsu Province, China. SSRN Electronic Journal. https://doi.org/10.2139/ssrn.3555539

Dewi, W. A. F. (2020). Dampak COVID-19 terhadap Implementasi Pembelajaran Daring di Sekolah Dasar. Edukatif: Jurnal Ilmu Pendidikan, 2(1). https://doi.org/10.31004/edukatif.v2i1.89

Drysdale, J. S., Graham, C. R., Spring, K. J., \& Halverson, L. R. (2013). An analysis of research trends in dissertations and theses studying blended learning. Internet and Higher Education, 7, 90-100. https://doi.org/10.1016/j.iheduc.2012.11.003 
Dwi, B., Amelia, A., Hasanah, U., \& Putra, A. M. (2020). Analisis Keefektifan Pembelajaran Online di Masa Pandemi Covid-19. Jurnal Pendidikan Guru Sekolah Dasar.

Ginting, S. (2013). Budaya Organisasi pada Dinas Pendidikan dan Olahraga Kota Cimahi. Universitas Padjadjaran.

Gunarsa, S. D., \& Gunarsa, Y. D. (2017). Psikologi Perkembangan Anak dan Remaja. In PT. BPK Gunung Mulia. Jakarta.

Herliandry, L. D., Nurhasanah, N., Suban, M. E., \& Kuswanto, H. (2020). Pembelajaran Pada Masa Pandemi Covid-19. JTP - Jurnal Teknologi Pendidikan, 22. https://doi.org/10.21009/jtp.v22i1.15286

Khoiroh, N., Munoto, \& Anifah, L. (2017). Pengaruh Model Pembelajaran Blended Learning dan Motivasi Belajar Terhadap Hasil Belajar Siswa. Jurnal Penelitian Ilmu Pendidikan, 10(2). https://doi.org/https://doi.org/10.21831/jpipfip.v10i2.13986

Kusuma, J. W., \& Hamidah, H. (2020). Perbandingan Hasil Belajar Matematika dengan Penggunaan Platform Whatsapp Group dan Webinar Zoom Dalam Pembelajaran Jarak Jauh pada Masa Pandemik COVID 19. Jurnal Ilmiah Pendidikan Matematika, 5(1). https://doi.org/10.26877/jipmat.v5i1.5942

Law of the Republic of Indonesia Number 14 of 2005 concerning Teachers and Lecturers. , (2005).

Manggabarani, A. F., Sugiarti, \& Masri, M. (2016). Pengaruh Model Pembelajaran Blended Learning Terhadap Motivasi dan Hasil Belajar Siswa Kelas X SMA Negeri 1 Pitumpanua Kab.Wajo (Studi Pada Materi Pokok Sistem Periodik Unsur). Chemica: Jurnal Ilmiah Kimia Dan Pendidikan Kimia, $17(2)$.

Masitoh, S. N., Yuliyanti, I. D., Lestari, U. D. A., \& Fitriyah, C. Z. (2018). Model Pembelajaran Berbasis Blended Learning Melalui Media Whatsapp dalam Menumbuhkan Critical Thingking pada Siswa SD. Prosiding FKIP Universitas Jember.

Mastura, \& Santaria, R. (2020). Dampak Pandemi Covid-19 terhadap Proses Pengajaran bagi Guru dan Siswa. Jurnal Studi Guru Dan Pembelajaran, 3(2).

Murfi, A., Fathurrochman, I., Atika, A., \& Saiva Jannana, N. (2020). Kepemimpinan Sekolah dalam Situasi Krisis Covid-19 di Indonesia. Manageria: Jurnal Manajemen Pendidikan Islam, 5(1). https://doi.org/10.14421/manageria.2020.51-07

Nakayama, M., Yamamoto, H., \& Santiago, R. (2007). The Impact of Learner Characteristics on Learning Performance in Hybrid Courses among Japanese Students. Electronic Journal of E-Learning, 5(1).

Nikmawati, I. S. (2014). Korelasi Gaya Belajar Siswa Kelas VII dengan Hasil Belajar Mata Pelajaran Sejarah Kebudayaan Islam di Sekolah Menengah Pertama (SMP) Islam Durenan Trenggalek. IAIN Tulungagung.

Obiakor, T., \& Adeniran, A. (2020). Covid-19: Impending Situation Threatens To Deepen Nigeria' S Education Crisis. Center For The Study Of The Economies Of Africa.

Pimmer, C. (2016). Mobile learning as boundary crossing: an alternative route to technology-enhanced learning? Interactive Learning Environments, https://doi.org/10.1080/10494820.2015.1128211

Rombot, O. (2020). Blended Learning: Apakah mungkin dilakukan di Tingkat Pendidikan Dasar? Retrieved March 20, 2021, from https://pgsd.binus.ac.id/2019/12/22/blended-learning-apakah-mungkindilakukan-di-tingkat-pendidikan-dasar/

Snelling, J., \& Fingal, D. (2020). 10 strategies for online learning during a coronavirus outbreak. Retrieved March 20, 2021, from https://www.iste.org/explore/learning-during-covid-19/10-strategies-onlinelearning-during-coronavirus-outbreak

Sugiyono. (2014). Metode Penelitian Kombinasi (Mixed Methods). Bandung: Alfabeta.

Suhartono. (2016). Menggagas Pendekatan Blended Learning di Sekolah Dasar. Prosiding Temu Ilmiah Nasional Guru. Retrieved from http://repository.ut.ac.id/6550/1/TING2016ST2-27.pdf

Wahyono, P., Husamah, H., \& Budi, A. S. (2020). Guru profesional di masa pandemi COVID-19: Review implementasi, tantangan, dan solusi pembelajaran daring. Jurnal Pendidikan Profesi Guru, 1(1).

Wardani, D. N., Toenlioe, A. J. E., \& Wedi, A. (2018). Daya Tarik Pembelajaran Di Era 21 Dengan Blended Learning. Jurnal Kajian Teknologi Pendidikan (JKTP), 1(1).

Widyaningsih, O., Yudha, C. B., \& Nugraheny, D. C. (2016). Pengembangan Model Blended Learning untuk Sekolah Dasar. JPD: Jurnal Pendidikan Dasar.

Wong, R. (2019). Basis psychological needs of students in blended learning. Interactive Learning Environments. https://doi.org/10.1080/10494820.2019.1703010

Yaumi, M. (2018). Media dan Teknologi Pembelajaran. Jakarta: Prenadamedia Group. 